\title{
Quality of life of high risk pregnant women during prenatal care
}

\author{
Qualidade de vida de mulheres com gravidez de alto risco durante o cuidado pré-natal \\ Calidad de vida de las mujeres embarazadas de alto riesgo durante la atención prenatal
}

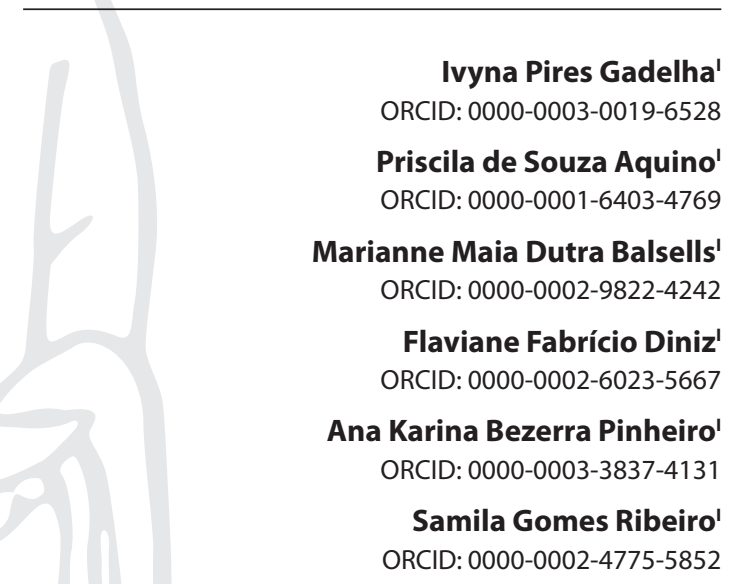

Régia Christina Moura Barbosa Castro' ORCID: 0000-0002-0673-9442

'Universidade Federal do Ceará. Fortaleza, Ceará, Brazil.

How to cite this article: Gadelha IP, Aquino PS, Balsells MMD, Diniz FF, Pinheiro AKB, Ribeiro SG, et al. Rev Bras Enferm. 2020;73(Suppl 5):e20190595. doi: http://dx.doi.org/10.1590/0034-7167-2019-0595

\section{Corresponding author: Ivyna Pires Gadelha ivynapires@gmail.com}

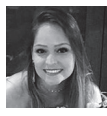

EDITOR IN CHIEF: Antonio José de Almeida Filho ASSOCIATE EDITOR: Hugo Fernandes

Submission: 08-09-2019

Approval: 01-10-2020

\begin{abstract}
Objective: to analyze the quality of life of high-risk pregnant women. Methods: an observational and cross-sectional study, carried out in a tertiary maternity hospital located in Fortaleza, with 276 high-risk pregnant women. A questionnaire was applied containing socioddemographic, clinical and obstetric data and The Mother-Generated Index. Descriptive analyzes were performed using the Jamovi statistical program", version 0.9. Results: most areas were negatively influenced by pregnancy. "Satisfaction with pregnancy", "family relationship" and "relationship with the partner" obtained the highest means of primary score, while "physical condition/disposition" and "financing" obtained the lowest means. The highest secondary scores were in "satisfaction with pregnancy","family relationship" and "relationship with the partner", while the lowest were in "financing" and "psychological/emotional". Conclusion: the total primary score mean was 6.03 , suggesting a good quality of life. The Mother Generated Index made it possible to identify aspects of life that go beyond pre-formulated assessments of the construct.
\end{abstract}

Descriptors: Quality of Life; Prenatal Care; Pregnancy, High-Risk; Nursing Care; Nursing.

\section{RESUMO}

Objetivo: analisar a qualidade de vida de gestantes de alto risco. Métodos: estudo observacional e transversal, realizado em uma maternidade terciária localizada em Fortaleza, com 276 gestantes de alto risco. Aplicou-se questionário contendo dados sociodemográficos, clínicos e obstétricos e o The Mother-Generated Index. Realizaram-se análises descritivas no programa estatístico Jamovi", versão 0.9. Resultados: a maioria das áreas foi influenciada negativamente pela gestação. "Satisfação com a gravidez", "relacionamento familiar" e "relacionamento com o parceiro" obtiveram as maiores médias de escore primário, enquanto que "condição física/disposição" e "financeiro" obtiveram as menores médias. Os maiores escores secundários foram em "satisfação com a gravidez","relacionamento familiar"e"relacionamento com o parceiro", enquanto os menores foram em "financeiro" e "psicológico/emocional. Conclusão: a média do escore primário total foi 6,03, sugerindo uma boa da qualidade de vida. 0 The Mother-Generated Index possibilitou identificar aspectos da vida que vão além de avaliações pré-formuladas do construto.

Descritores: Qualidade de Vida; Cuidado Pré-Natal; Gravidez de Alto Risco; Cuidados de Enfermagem; Enfermagem.

\section{RESUMEN}

Objetivo: analizar la calidad de vida de las embarazadas de alto riesgo. Métodos: estudio observacional y transversal realizado en maternidad terciaria de Fortaleza, con 276 mujeres embarazadas de alto riesgo. Se aplicó un cuestionario que contenía datos sociodemográficos, clínicos, obstétricos, también The Mother-Generated Index. Se utilizó el software Jamovi", versión 0.9. Resultados: la mayoría de las áreas fueron influenciadas negativamente. "Satisfacción con el embarazo","relación familiar"y"relación con la pareja" obtuvieron los promedios de puntaje primario más altos, mientras que "condición física/disposición" y "financiero" obtuvieron los más bajos. Los puntajes secundarios más altos fueron "satisfacción con el embarazo", "relación familiar" y "relación con la pareja", mientras que los más bajos fueron "financieros" y "psicológicos/emocionales". Conclusión: la puntuación primaria total promedio fue de 6.03, lo que sugiere ser bueno. Fue posible identificar aspectos de la vida que van más allá de las evaluaciones de construcciones preformuladas.

Descriptores: Calidad de Vida; Atención Prenatal; Embarazo de Alto Riesgo; Atención de Enfermería; Enfermería. 


\section{INTRODUCTION}

Pregnancy consists of a period surrounded by numerous changes in the woman's body, which can be related to the physical and psychological domains of health, with the potential to interfere in the perception of the quality of life (QoL) of this population. It is known that, regardless of maternal health status or pre-existing complications, the worsening of mood and the decrease in physical QoL occur as a result of these expected physiological changes ${ }^{(1)}$.

Since the changes inherent to the usual risk pregnancy can interfere in the QoL of women, the condition of high gestational risk stands out, in which there is a greater probability of achieving unfavorable results, both for the mother and the fetus ${ }^{(2)}$. It is noteworthy that previous complications or during pregnancy, as well as obesity and symptoms related to pregnancy are the main factors related to the worsening of the QoL of pregnant women ${ }^{(3)}$.

From the point of view of QoL, the "Health-Related Quality of Life" is emphasized, a term that refers to aspects directly related to health status, involving its influence on an individual's perception of well-being. Its multidimensional character is highlighted, which includes physical, psychological and social conditions and reflects the experience of each individual ${ }^{(4)}$.

In this setting, it is considered that knowing the profile of women inserted in the context of high-risk pregnancy enables the initial recognition of possible factors that influence the process of adaptation to the pregnancy period and, consequently, the QoL.

Thus, there is a need to value these aspects in the prenatal consultations carried out, as well as the insertion of instruments that facilitate the identification of areas of life that are strengthened and weakened, in order to establish, together with the strategies for promoting well-being.

The present study sought to assess the QoL of pregnant women by identifying the areas of life that are most affected by high-risk pregnancies, as well as understanding how they feel about it, in order to recognize their influence on QoL.

In this perspective, the guiding question is: what are the main areas of life of pregnant women affected by high-risk pregnancies?

\section{OBJECTIVE}

To assess the QoL of high-risk pregnant women.

\section{METHODS}

\section{Ethical aspects}

The study was submitted to the Maternity Research Ethics Committee, as recommended by Resolution 466/12 of the Brazilian National Health Board (Conselho Nacional de Saúde) ${ }^{(5)}$, which refers to research involving human beings, being approved.

Women were guaranteed compliance with the ethical precepts of beneficence, non-maleficence and justice, as well as the participant's right to anonymity and her autonomy as to participating in the research without any prejudice.

Cultural, moral and religious values were respected, and there was no influence on the part of the interviewers.
The ICF was provided to all pregnant women who agreed to participate in the research.

\section{Study design, period and location}

This is an observational and cross-sectional study, guided by the STROBE tool, developed from August to November 2018, in a tertiary maternity hospital, linked to the single health system, considered one of the reference units for the pre -natural high risk in the state of Ceará.

High-risk prenatal care takes place in the maternal-fetal outpatient clinic and has a multidisciplinary apparatus for women. The team is composed of nurses, nursing technicians, psychologist, social worker and nutritionist, in addition to the various medical specialties, namely: obstetrics, genetics, psychiatry, endocrinology and cardiology.

\section{Population or sample}

The non-probabilistic sample was used for convenience. The final sample consisted of 276 high-risk pregnant women.

\section{Inclusion and exclusion criteria}

Pregnant women followed up in high-risk prenatal care at that maternity hospital were included, with a confirmed diagnosis of high gestational risk.

Pregnant women in a psychotic break or with disabilities that prevented them from responding to the survey were excluded, as it could impair the development of the interview.

\section{Study protocol}

Data collection was carried out by the researcher herself and by two collaborators, who were trained in the collection procedures, and it took place through interviews and consultation of the medical record and the prenatal card. The interviews took place individually, in a private room and at an appropriate time - before or after consultations. A structured instrument was produced, produced by the author herself, which contained information about the sociodemographic, clinical and obstetric data of the pregnant women and The Mother-Generated Index (MGI), related to QoL.

They stand out as sociodemographic variables, namely: age, education, race, marital status, family income, work activity and municipality of residence. Furthermore, the clinical-obstetric variables assessed were body mass index, use of medications, early prenatal care, gestational trimester, number of live children, pregnancy planning, hospitalization during pregnancy and reason for monitoring high-risk prenatal care.

MGI was originally developed with postpartum women in the United Kingdom ${ }^{(6)}$ and had its translation, adaptation and validation for use in Brazil in 2013 ${ }^{(7)}$. Its applicability in women in the gestational period stands out ${ }^{(8)}$. The survey stands out for allowing the understanding of the aspects that involve QoL according to the woman's perception ${ }^{(7)}$, subsidizing the improvement of the assistance provided. 
In addition, it consists of a three-step instrument. The first step involves pointing out areas of life that are important to you and that were influenced by pregnancy, in addition to indicating how these areas were affected (positively, negatively or both/none). The second stage deals with the score of each area, in order to mention how they feel about them, which can vary from zero to 10. The closer to zero, the worse the woman felt, while the closer to 10 , the better the woman felt. The third stage is the distribution of 20 points, according to the importance that each area has on the QoL of women. The higher the score, the more important the area is for its QoL. The index generates two scores. The primary score is defined as the mean of the scores in step 2. The secondary score consists of the weighted mean of the scores in step 2 with the weights given in step $3^{(9)}$.

\section{Analysis of results and statistics}

The data were placed in an EXCEL database and descriptive analyzes were performed using Jamovi', version 0.9. Medians, interquartile range, absolute frequencies and prevalence rates were verified. We chose to use the median since $p<0.05$, according to the Komolgorov-Smirnov test, showing deviation from normality. The results were categorized and presented in tables. Subsequently, they were discussed according to the relevant literature.

\section{RESULTS}

As for the sociodemographic data, it was observed that the sample was composed mainly of young adult pregnant women, with a median age of 30 years; who had secondary education, 175 (63.4\%), and family income of 1 to 3 minimum wages, 148 (53.6\%); did not exercise paid activity, 172 (62.3\%); lived with their partner, 232 (84.1\%); lived in the capital, 222 (80.4\%); were mixed-race, 223 (80.8\%), and Catholic, 131 (47.5\%).

Regarding clinical and obstetric data, most women started prenatal care up to 12 weeks of pregnancy, 169 (61.2\%), were in the third gestational trimester, 160 (58\%); had up to two living children, 253 (91.7\%); did not plan the pregnancy, 167 (60.5\%); had an inadequate Body Mass Index, 207 (75\%), and used drugs, 199 (72.1\%). Of the interviewees, 61 (22.1\%) experienced hospitalization during pregnancy. There was a total of 612 indications for high risk, highlighting the possibility of a pregnant woman presenting more than one reason for monitoring the service, with a mean of 2.2 conditions per woman. Most indications for high-risk prenatal care were related to problems in current pregnancy, 276 (45.1\%). The most prevalent diagnosis was gestational Diabetes Mellitus, 81 (13.3\%).

Through the application of MGI (Brazilian version), it was possible to observe that 45 areas in the life of pregnant women were affected by pregnancy, with a total of 1,306 responses being verified, equivalent to a mean of 4.73 aspects cited per woman. In this research, the 10 most cited areas were highlighted, namely: food, sleep, family, psychological/emotional relationship, relationship with the partner, physical disposition/condition, work, satisfaction with pregnancy, financing, and health.

Table 1 describes the ten most affected areas in the QoL of high-risk pregnant women, according to the application of MGI (Brazilian version).

According to step 1 of the instrument, the areas were categorized as positive, negative or both/none. Among the main aspects pointed out, $42.9 \%$ (389) were positive, $48 \%$ (436) were negative and $9.1 \%$ (83) were both/none.

The area "satisfaction with pregnancy" was predominantly pointed out as a positive change, 57 (95\%), as well as "family relationship", 93 (80.2\%), "relationship with the partner", 60 (65.2\%), and "food", 97 (58.8\%). Adversely, "disposition/physical condition" was reported, mainly, as a negative area, 67 (85.9\%), as well as "financing", 44 (75.9\%), "health", 32 (72.7\%), "sleep", 86 (69.9\%), "work", 52 (69.3\%), and "psychological/emotional", 62 (63.9\%).

As evidenced in step 2, the mean of the scores for the positive areas was $9.06( \pm 1.72)$, for the negative ones it was $3.63( \pm 2.70)$ and for the areas both/none was $6.40( \pm 2.52)$. The "satisfaction with pregnancy" aspect, related to the positive environment, was the one with the highest mean score, $9.82( \pm 0.50)$. The following areas also obtained scores close to 10 , in the positive scope: "family relationship", $9.72\left({ }^{ \pm} 0.63\right)$, "relationship with the partner", $9.56( \pm 0.67)$, and "health", $9.28( \pm 0.95)$.

On the other hand, in a negative context, the lowest mean found in step 2 was also in the aspect "satisfaction with pregnancy", $2.50( \pm 3.53)$ points. The other scores closest to zero, in the negative scope, were "family relationship", $2.78( \pm 1.84)$, and "relationship with the partner", 2.95 (³.38).

Table 1 - Scores distribution of steps 1, 2 and 3 of The Mother-Generated Index (MGI), according to the ten areas of Quality of Life most pointed out by high-risk pregnant women, Fortaleza, Ceará, Brazil

\begin{tabular}{|c|c|c|c|c|c|c|c|c|c|c|}
\hline \multirow[b]{2}{*}{ Areas of quality of life } & \multirow[b]{2}{*}{ Total / \% } & \multicolumn{3}{|c|}{ Positive } & \multicolumn{3}{|c|}{ Negative } & \multicolumn{3}{|c|}{ Both / none } \\
\hline & & $\begin{array}{l}\text { Step } 1 \\
n(\%)\end{array}$ & $\begin{array}{c}\text { Step } 2 \\
\text { Mean (SD) }\end{array}$ & $\begin{array}{c}\text { Step } 3 \\
\text { Mean (SD) }\end{array}$ & $\begin{array}{c}\text { Step } 1 \\
\text { n(\%) }\end{array}$ & $\begin{array}{c}\text { Step } 2 \\
\text { Mean (SD) }\end{array}$ & $\begin{array}{c}\text { Step } 3 \\
\text { Mean (SD) }\end{array}$ & $\begin{array}{c}\text { Step } 1 \\
\text { n(\%) }\end{array}$ & $\begin{array}{c}\text { Step } 2 \\
\text { Mean (SD) }\end{array}$ & $\begin{array}{c}\text { Step } 3 \\
\text { Mean (SD) }\end{array}$ \\
\hline Food & $165(59.7)$ & $97(58.8)$ & $8.82(+1.63)$ & $4.90(+4.04)$ & $53(32.1)$ & $4.07(+2.89)$ & $3.55(+3.36)$ & $15(9.1)$ & $6(+2.36)$ & $5.8(+5.57)$ \\
\hline Sleep & $123(44.5)$ & $30(24.4)$ & $7.53(+2.88)$ & $2.56(+2.16)$ & $86(69.9)$ & $4.18(+2.47)$ & $3.56(+3.86)$ & $7(5.7)$ & $7.71(+2.13)$ & $5.71(+7.18)$ \\
\hline Family relationship & $116(42.0)$ & $93(80.2)$ & $9.72\left({ }^{+} 0.63\right)$ & $6.38(+3.85)$ & $14(12.1)$ & $2.78(+1.84)$ & $4.5(+4.89)$ & $9(7.7)$ & $6.66(+2.82)$ & $5.11(+6.48)$ \\
\hline Psychological/emotional & $97(35.1)$ & $16(16.5)$ & $7.75(+2.20)$ & $3.81(+2.13)$ & $62(63.9)$ & $3.58(+2.82)$ & $2.37(+2.51)$ & 19 (19.6) & $4.89(+2.55)$ & $3.57(+3.37)$ \\
\hline Relationship with partner & $92(33.3)$ & $60(65.2)$ & $9.56\left({ }^{+} 0.67\right)$ & $6.02(+4.37)$ & $24(26.1)$ & $2.95(+3.38)$ & $2.45(+3.28)$ & $8(8.7)$ & $8(+2.77)$ & $5.12(+3.56)$ \\
\hline Disposition/physical condition & $78(28.2)$ & $5(6.4)$ & $5.8(+2.77)$ & $5.4(+4.44)$ & $67(85.9)$ & $3.46(+2.51)$ & $3.70(+3.90)$ & $6(7.7)$ & $7(+2.44)$ & $3.66(+3.72)$ \\
\hline Work & $75(27.1)$ & $14(18.7)$ & $7.64(+3.02)$ & $3.71(+4.00)$ & $52(69.3)$ & $3.40(+2.70)$ & $2.69(+2.76)$ & $9(12)$ & $6.22(+2.16)$ & $3.88(+2.97)$ \\
\hline Satisfaction with pregnancy & $60(21.7)$ & $57(95)$ & $9.82\left({ }^{+} 0.5\right)$ & $8.42\left({ }^{+} 6.01\right)$ & $2(3.3)$ & $2.5(+3.53)$ & $10\left(^{+} 14.14\right)$ & $1(1.7)$ & 6 & 0 \\
\hline Financing & $58(21.0)$ & $10(17.2)$ & $8(+2.53)$ & $1.3\left({ }^{+} 1.94\right)$ & $44(75.9)$ & $3.52(+2.75)$ & $3.56(+3.61)$ & $4(6.9)$ & $6.5(+1.29)$ & $5.5(+3)$ \\
\hline Health & $44(15.9)$ & $7(15.9)$ & $9.28\left({ }^{+} 0.95\right)$ & $3.14(+2.26)$ & $32(72.7)$ & $3.37(+2.79)$ & $5.56(+6.20)$ & $5(11.4)$ & $8.2(+1.78)$ & $1.8(+2.48)$ \\
\hline Total / Mean (SD) & 908 & 389 (42.9) & $9.06(+1.72)$ & $5.56(+4.48)$ & $436(48.0)$ & $3.63(+2.70)$ & $3.45(+3.87)$ & $83(9.1)$ & $6.40(+2.52)$ & $4.45(+4.54)$ \\
\hline
\end{tabular}


Regarding the mean of points attributed in step 3, it was observed that for positive comments it was $5.56( \pm 4.48)$, for negative ones it was $3.45( \pm 3.87)$ and for both/none was $4.45( \pm$ 4.54). It was observed that, in the positive context, the lowest weight was attributed to the "financing" area, $1.3( \pm 1.94)$, while the highest weight was attributed to the "satisfaction with pregnancy" area. On a negative basis, it was possible to verify that the lowest weight was attributed to the "psychological/emotional" area, $2.37( \pm 2.51)$, while the highest weight was attributed to the "satisfaction with pregnancy" area. Regarding both/none, it was noticed that the lowest weight was attributed to the area "satisfaction with pregnancy", zero, while the highest weight was to the area "food", $5.8( \pm 5.57)$.

This finding corroborates the fact that"satisfaction with pregnancy" greatly interferes with the QoL of high-risk pregnant women, since, both in the positive and negative spheres, it received the greatest weight, meaning greater importance on the QOL.

Table 2 shows the scores of primary and secondary scores, according to the areas of MGI (Brazilian version) most cited by pregnant women.

Table 2 - Calculation of primary and secondary scores of The MotherGenerated Index (MGI) according to the ten areas of Quality of Life most cited by pregnant women, Fortaleza, Ceará, Brazil

\begin{tabular}{lcc}
\hline Áreas afetadas & $\begin{array}{c}\text { MGI primary } \\
\text { score } \\
\text { Mean (+SD) }\end{array}$ & $\begin{array}{c}\text { Secondary MGI } \\
\text { score } \\
\text { Mean }\end{array}$ \\
\hline Food & $7.04(+3.08)$ & 1.68 \\
Sleep & $5.20(+2.98)$ & 0.94 \\
Family relationship & $8.64(+2.58)$ & 2.71 \\
Psychological/emotional & $4.52(+3.06)$ & 0.69 \\
Relationship with partner & $7.70(+3.46)$ & 2.15 \\
Disposition/physical condition & $3.88(+2.71)$ & 0.77 \\
Work & $4.53(+3.19)$ & 0.81 \\
Satisfaction with pregnancy & $9.51(+1.55)$ & 3.96 \\
Financing & $4.50(+3.16)$ & 0.66 \\
Health & $4.86(+3.48)$ & 1.14 \\
Total & $6.03(+2)$ & 1.49 \\
\hline
\end{tabular}

Note: MGI - The Mother-Generated Index.

Regarding the primary score, achieved through the overall mean of scores obtained in all areas (positive, negative and both/none), "satisfaction with pregnancy" was also the one that obtained the highest mean $(9.51 \pm 1.55)$, followed by "family relationship", $8.64( \pm 2.58)$ and "relationship with partner", $7.70( \pm$ 3.46). "Physical condition/disposition" obtained the lowest mean primary score, $3.88( \pm 2.71)$, followed by "financing", $4.50( \pm 3.16)$, and "psychological/emotional", $4.52( \pm 3.06)$.

The total mean of primary scores (means of all scores, from zero to ten, assigned in step 2) was 6.03, demonstrating a relatively positive assessment of QoL, since women assigned scores greater than five.

As for the secondary scores, the area that obtained the highest score was "satisfaction with pregnancy", 3.96, followed by "family relationship", 2.71, and "relationship with the partner", 2.15. It is noteworthy that these areas were considered by most women to be positive, being more important for pregnant women. "Financing" was the area with the lowest score, 0.66 , followed by "psychological/emotional", 0.69 and "physical condition/disposition", 0.77, meaning less relevant areas for pregnant women and considered by the majority as negative. The areas categorized under both/ none were less prevalent.

\section{DISCUSSION}

It is known that sociodemographic conditions, such as age, education, race, income and marital status, and the clinical and obstetric characteristics of patients, such as the number of children, gestational age and obstetric history, significantly interfere with their psychosocial aspects, such as depressive symptoms, the state of anxiety and the perception of social support ${ }^{(10)}$, which may reflect on its QoL.

Religion also stands out in this context, due to its positive influence on QoL by encouraging the confrontation of adverse conditions through faith ${ }^{(11)}$. Furthermore, considering the possibility of hospitalization linked to the condition of high risk, its negative influence on this construct is emphasized, since it is related to feelings such as anger, frustration and loneliness ${ }^{(12)}$.

Respecting the multidimensional character of QoL, the application of MGl enabled the recognition of the areas of life affected by pregnancy according to the perception of the women themselves, which differs from the other measurement instruments, making it startling.

It was possible to notice that "food","family relationship","relationship with the partner" and "satisfaction with pregnancy" were areas mentioned mainly as positive, while"sleep", "psychological/ emotional", "disposition/physical condition", "work", "financing" and "health" were areas mainly cited as negative.

Although most aspects were related to the negative character, it was found that the total primary score of the scale was relatively good, 6.03, as it was closer to 10, indicating that women felt good about their areas of life. The primary score found in this investigation was higher than that found among low-risk pregnant women, confirming that, in addition to the patients clinical conditions, other factors influence QOL, such as age, occupation, marital status, partner support, people with whom women live and life habits ${ }^{(8)}$.

It is noteworthy that "satisfaction with pregnancy", "family relationship" and "relationship with the partner"were those that obtained the highest and lowest mean scores in step 2, considering the positive and negative scope, respectively. It is essential to emphasize that these women also demonstrated to have a high weight on QoL, suggesting that they represent an extreme of feelings for the pregnant woman, both in the positive and in the negative, since the scores attributed indicate that they feel extremely happy or extremely unhappy about these aspects.

Similar to the present study, in which the highest score in step 2 focused on "satisfaction with pregnancy", the area with the highest score among low-risk pregnant women was "happy to be a mother", confirming the importance of this moment in life of a woman ${ }^{(8)}$. However, it is essential to know the other factors that involve the pregnancy process and the acceptance of the pregnancy, since dissatisfaction with pregnancy interferes very negatively in the QoL of the pregnant woman.

Although satisfied with the fact of being a mother, there was an important influence of the relationship with the family and 
the partner on the woman's QoL. From this perspective, the importance of support for pregnant women is revealed, which contributes positively to QoL and the acceptance of pregnancy. There is a positive relationship between social support and health-related QoL ${ }^{(13)}$.

With regard to "food", it was observed that this was the most cited area among pregnant women, which may be related to the profile of pregnant women who are obese or with complications such as diabetes, a factor that is consistent with the greater need to change eating habits. Regarding its importance on QoL, it was noticed that whoever evaluated it in a positive character, referred it as more important compared to those who evaluated it in the negative. Pregnant women who reported "food" in character both/none, gave even more importance.

It is known that maintaining a balanced diet during pregnancy is necessary and pregnant women today are more aware of the need to maintain a healthy eating habit ${ }^{(14)}$, which may justify the fact that this change was mainly pointed out as a positive aspect. It is worth noting that the pregnant women involved in the present study enjoyed nutritional monitoring, which may have favored a more positive assessment of this aspect.

Regarding "sleep", it was found that it was the second most cited area, with a predominance of negative notes, which can be justified by the high prevalence of disorders in the gestational period ${ }^{(15)}$. Corroborating, there was a low quality of sleep in high-risk pregnant women in Iran, in addition to its statistically significant relationship with their QoL ${ }^{(16)}$.

Although the high prevalence of changes in sleep during the gestational period is recognized, with regard to the influence of this aspect on QoL, a relatively low weight in the positive and negative spheres was evidenced, with the greatest importance being mentioned among the neutral notes. In view of the high prevalence of sleep disorders among pregnant women, it is essential that nursing care values this aspect through educational technology, in order to promote greater well-being.

"Work" and "financing" were primarily pointed out in a negative way. It is believed that work may be linked to the financial issue. Most of the sample was unemployed, which may reflect a greater chance of financial fragility, since the arrival of a new child indicates an increase in expenses.

Corroborating with the findings of the present study, it was evidenced that "work" was pointed out as one of the most cited areas and with the greatest negative influence on the QoL of low-risk pregnant women ${ }^{(8)}$.

In addition, it is emphasized that "financing" is directly related to psychological issues. Women dissatisfied with financial quality have lower levels of QoL and a higher risk of developing depression $^{(17)}$. In the present study, it was observed that, among those who indicated this area as positive, weight had a considerably low influence, however, among pregnant women who reported it as negative, it was possible to show more importance, corroborating the finding of another study ${ }^{(17)}$.

With regard to the "psychological/emotional" aspect, also seen mainly as a negative change, it is possible to draw an analogy with the high-risk clinical conditions that women experience, in addition to the social and economic scenario in which they are inserted, which can lead to them to the peak of psychic suffering. From this perspective, it is considered that both intrinsic and extrinsic factors to pregnancy can trigger fears and anxieties in pregnant women, damaging their QoL. It is also emphasized the need for psychological monitoring of these women, since the reframing of difficult experiences favors the improvement of QoL ${ }^{(18)}$. Despite this, it was noticed that the weight of this area on QoL is relatively low, in all areas, perhaps this is due to the psychological monitoring to which the women in the study are subject.

In view of the profile of investigated, high-risk pregnant women, the predominance of negative notes related to "health" was expected. Some authors have observed that pregnant women with previous or current complications, obesity and the presence of symptoms related to pregnancy are among the main factors associated with worse QoL ${ }^{(3)}$. It was observed that among pregnant women who related health to the positive environment, they reported a relatively low weight on QoL. Adversely, it was found that those who pointed it in the negative context gave greater importance, suggesting an association between worse clinical conditions and worse QoL, as highlighted by the other authors mentioned above.

Regarding "disposition/physical condition", there was a predominance of negative notes. It should be noted that the changes that occur in the maternal body during pregnancy may reflect a decrease in energy and an increase in fatigue ${ }^{(19)}$, justifying this finding among the present sample. Pregnant women who pointed out this aspect in the positive character gave a relatively high importance on the QoL, whereas for those who related this aspect to the negative or neutral character, they mentioned a lower weight.

\section{Study limitations}

As limitations of the study, we highlight the cross-sectional design, which did not allow estimating the temporal evolution of the aspects that influence QoL during pregnancy, and the scarcity of studies that evaluate QoL in women with high-risk pregnancies, inhibiting comparisons most valuable.

\section{Contributions to nursing}

The present study enabled prenatal nurses to recognize the aspects that influence the QoL of high-risk pregnant women under the eyes of the woman, a contribution that favors the direction of educational practices with a holistic and comprehensive approach, involving women in all areas of its life. The importance of making the assessment of women's QoL during the gestational period becomes evident, aiming to promote maternal-fetal well-being. The study fills a gap in scientific knowledge and supports professional guidance and future research. In addition, it is essential that new studies include pregnant women from the private health service, in order to compare the groups.

\section{CONCLUSION}

It was possible to confirm that the changes experienced during pregnancy are capable of influencing the perception of QoL, both positively and negatively. It was evident that most of the affected areas were predominantly identified as a negative 
change, although the mean of the total primary score was above half (6.03), suggesting a good perception of QoL.

MGl use became essential, because, through its qualitative approach, it respected the multifactorial character of QoL, enabling the identification of aspects that go beyond pre-formulated assessments of the construct.

Notably, the areas that most influenced the QoL of high-risk pregnant women were "satisfaction with pregnancy", "family relationship" and "relationship with the partner". In contrast, those that least interfered with QoL were "financing", "psychological/ emotional" and "physical condition/disposition".

Knowing the areas of life that suffer the most changes with pregnancy and most interfere in QoL subsidizes assistance in a holistic way. The recognition of affected areas positively and negatively under the perception of the women themselves can guide the creation of strategies in order to improve their QoL.

\section{REFERENCES}

1. Altazan AD, Redman LM, Burton JH, Beyl RA, Cain LE, Sutton EF, et al. Mood and quality of life changes in pregnancy and postpartum and the effect of a behavioral intervention targeting excess gestational weight gain in women with overweight and obesity: a parallel-arm randomized controlled pilot trial. BMC Pregnancy Childbirth. 2019;19 (50). doi: 10.1186/s12884-019-2196-8.

2. Secretaria de Saúde do Estado do Ceará. Nascer no Ceará: condutas assistenciais para a linha de cuidado materno-infantil do estado do Ceará [Internet]. Fortaleza: Littere; 2018 [cited 2019 Jul 03]. 160 p. Available from: https://www.saude.ce.gov.br/wp-content/uploads/ sites/9/2018/10/condutas_assistenciais_projeto_nascer_no_cear\%C3\%A1_12_de_novembro_2018.pdf

3. Lagadec N, Steinecker M, Kapassi A, Magnier AM, Chastang J, Robert S, et al. Factors influencing the quality of life of pregnant women: a systematic review. BMC Pregnancy Childbirth. 2018;18 (1):455. doi: 10.1186 / s12884-018-2087-4.

4. Bai G, Raat H, Jaddoe VWV, Mautner E, Korfage IJ. Trajectories and predictors of women's health-related quality of life during pregnancy: a large longitudinal cohort study. PLoS ONE. 2018;13 (4):e0194999. doi: 10.1371/journal.pone.0194999

5. Ministério da Saúde (BR), Conselho Nacional de Saúde. Resolução n 466, de 12 de dezembro de 2012. Dispõe sobre diretrizes e normas regulamentadoras de pesquisa envolvendo seres humanos [Internet]. Brasília; 2012 [cited 2018 Mar 20]. Available from: http://bvsms.saude. gov.br/bvs/saudelegis/cns/2013/res0466_12_12_2012.html

6. Symon A, Macdonald A, Ruta D. Postnatal quality of life assessment: introducing the Mother-Generated Index. BIRTH. 2002;29(1):40-6. doi: 10.1046/j.1523-536X.2002.00154.x

7. Ribeiro SG, Lessa PRAS, Aquino PS, Pinheiro AKB, Symon A, Oliveira MF, et al. Translation and cultural adaptation of the Mother-Generated Index into Brazilian Portuguese: a postnatal quality of life study. Midwifery. 2015;31(7):735-41. doi: 10.1016/j.midw.2015.03.009

8. Calou CGP, Oliveira MF, Carvalho FHC, Soares RAL, Bezerra RA, Lima, SKM, et al. Maternal predictors related to quality of life in pregnant women in the Northeast of Brazil. Health Qual Life Outcomes. 2018;16 (109). doi: 10.1186/s12955-018-0917-8.

9. Ribeiro SG. Tradução, adaptação e validação do The Mother Generated Index para uso no Brasil. [Dissertation on the Internet]. Fortaleza: Universidade Federal do Ceará; 2013 [cited 2019 May 20]. 121 p. Available from: http://www.repositorio.ufc.br/bitstream/riufc/5569/1/2013_ dis_sgribeiro.pdf

10. Carvalho LL. Fatores psicossociais e gestação de alto risco: um estudo exploratório no município de Juiz de Fora/MG. [Dissertação] [Internet]. Juiz de Fora: Universidade Federal de Juiz de Fora; 2018. [cited 2019 Jan 10]. 97 p. Available from: https://repositorio.ufjf.br/jspui/ bitstream/ufff/6609/1/laislagedecarvalho.pdf

11. Aldrighi JD, Wall ML, Souza SRRK. Experience of pregnant women at an advanced age. Rev Gaúcha Enferm. 2019;39:e2017-0112. doi: 10.1590/1983-1447.2018.2017-0112

12. Kent RA, Yazbek M, Heyns T, Coetzee I. The support needs of high-risk antenatal patients in prolonged hospitalization. Midwifery. 2015;31(1):164-9. doi: 10.1016 / j.midw.2014.08.003

13. Gul B, Riaz MA, Batool N, Yasmin H, Riaz MN. Social support and health related quality of life among pregnant women. JPMA [Internet]. 2018 [cited 2019 Jun 15];68(6):872-5. Available from: https://jpma.org.pk/article-details/8720?article_id=8720

14. Moura AR, Azevedo FHC. Evidências científicas sobre a alimentação de gestantes. Rev Saúde Foco. 2018;5(1):78-90. doi: 10.12819/rsf.2018.5.1.5

15. Tsai SY, Lee PL, Lin JW, Lee CN. Cross-sectional and longitudinal associations between sleep and health related quality of life in pregnant women: a prospective observational study. Int J Nurs Stud. 2016;56:45-53. doi: 10.1016/j.ijnurstu.2016.01.001

16. Saadati F. Shafaei FS, Mirghafourvand M. Sleep quality and its relationship with quality of life among high-risk pregnant women (gestational diabetes and hipertension). J Maternal-Fetal Neonat Med. 2018;31(2):150-7. doi: 10.1080 / 14767058.2016.1277704

17. Sharakorpi N, Koivusalo SB, Eriksson JG, Kautiainen H, Stach-Lempinen B, Roine RP. Perceived financial satisfaction, health related quality of life and depressive symptoms in early pregnancy. Matern Child Health J. 2017;21(7):1493-99. doi: 10.1007/s10995-017-2271-6

18. Caldas DB, Silva ALR, Boing E, Crepaldi MA, Custódio ZAO. Atendimento psicológico no pré-natal de alto-risco: a construção de um serviço. Psicol Hosp [Internet]. 2013 [cited 2019 Jun 4];11 (1):66-87. Available from: http://pepsic.bvsalud.org/scielo.php?script=sci_arttext\&pid $=$ S1677-74092013000100005

19. Castro DFA, Fracolli LA. Qualidade de vida e promoção da saúde: em foco as gestantes. Mundo Saúde [Internet]. 2013 [cited 2019 Jun 5];37(2):159-65. Available from: http://bvsms.saude.gov.br/bvs/artigos/mundo_saude/qualidade_vida_promocao_saude_gestantes.pdf 